\title{
Evaluation of ground management in underground excavation design
}

\author{
B Rahimi Curtin University, Australia \\ M Sharifzadeh Curtin University, Australia
}

\begin{abstract}
A variety of challenges and problems are encountered by unstable rock failure which is associated with in situ stress, geological structures, geometry, excavation sequence, groundwater and operational conditions. It is basically required predicting ground behaviour and rock failure mechanism in a modern design of underground excavations. The complexity of ground conditions and uncertainties make it more difficult to control and avoid occurrences of failure. Ground management is a process to predict rock mass behaviour and failure modes, and apply proper ground support systems. Hazard identification and failure mechanism assessments assist in selecting suitable design method(s) to manage risks. The aim of this paper is to consider the main types of rock structure and rock mass behaviour modes to outline ground management in underground excavation design. Evaluation of rock mass instability conditions by proper design methods can provide a safe environment in working stopes. The Karari underground gold mine has been used as a case study. The rock mass structure was characterised as jointed/blocky/bedded class and ground behaviour types identified for evaluation were 'intact rock failure', 'structural failure' and 'water effect'. The primary planning for ground management established to evaluate rockbolts, mesh and shotcrete as a ground support system, and using smooth blasting/sequential excavation method in faults and shear zones to control possible failures in the portal access of the mine.
\end{abstract}

Keywords: rock mass structure, ground behaviour, ground management, underground excavation design, ground support system

\section{Introduction}

Ground control and management is associated with various potential failures and attempts to minimise the risks from rock hazards in underground excavations. Prediction of rock mass behaviour is a primary concern related to instability issues in design of openings. Design procedures usually consist of considering location, size and shape, layout, excavation method, support and reinforcement systems and monitoring (Bieniawski 1992). The collection and analysis of data, implementation, quality control and instrumentation are the main process elements of design to provide a stable environment in rock structures (Lang 1995). Stille and Palmstrom (2003) proposed a design approach based on field observations, characterisation and application of information as well as engineering experience. In the past three decades, ground control or management has been considered in the modern mine design process and it is an important factor in assessing the success or fail on mine operations (Peng 2007). Assessing the ground behaviour and failure modes is an indispensable step in pillar design, the design of ground support, roof and wall control in underground stopes, determining the extraction ratio and the selection of appropriate instrumentation. Ground control in underground excavation design can be carried out both for the initial design and for the modified design during the whole life of projects. Wayne Gretzky, regarded by many as the greatest ice hockey player ever said, "Skate to where the puck is going, not where it is and if you cannot predict, you will never become a good hockey player". Similarly, a good rock engineer needs to anticipate otherwise, it is not possible to be a good ground engineer (Cai 2013).

This paper considers a ground management procedure in underground excavation design. The process is shown in Figure 1. Rock mass structure is used to estimate the inherent properties of rock mass needed for 
predicting ground behaviour. Understanding the ground conditions makes it possible to assess instability conditions and failure mechanisms in the rock mass surrounding underground excavations. Based on the diagnosis of ground behaviour and failure mechanism, it is possible to select the appropriate tool(s) for design analysis. The results of design analysis determine the required ground support system, extraction rate and excavation sequence in underground practices. During the construction stage, sequential excavation is performed if necessary, ground support is installed and quality control of material is implemented. Reduction of uncertainties in the rock mass properties, and modification and update of design parameters during construction or after construction can be carried out by field measurements. In the following sections, the important processes will be discussed along with example from the Karari mine as a case study.

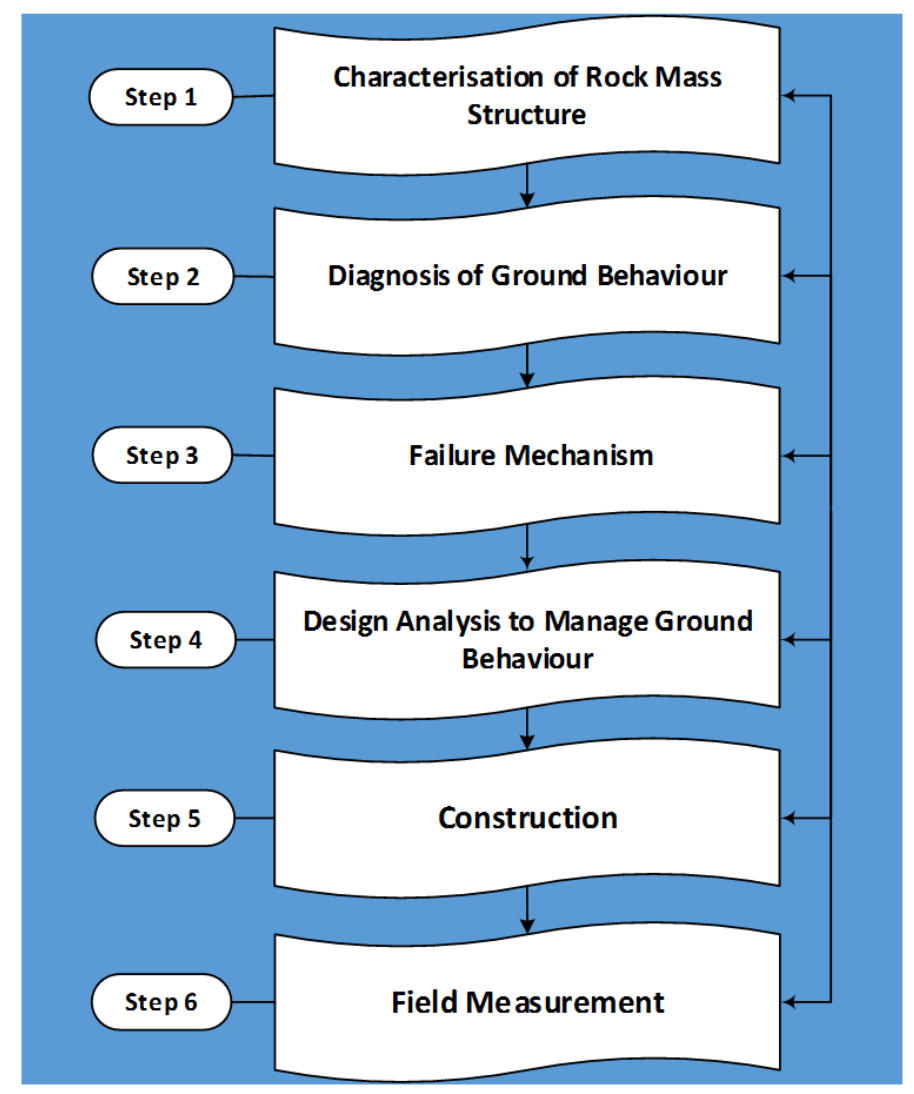

Figure 1 The ground management procedure in an underground excavation design

\section{Characterisation of rock mass structure}

Rock mass structure appraisal is an essential step in many underground projects. It is associated with determining inherent rock properties such as intact rock strength and providing a context for rock mass classification in design procedures (Potvin et al. 2015). Rock mass materials are composed of all unit elements of rock blocks and discontinuities. The primary important parameters for rock mass description for engineering purposes are colour, weathering, discontinuities, stratigraphic and rock type. Colour often provides a guide to identify rock type, weathering and composition of the rock. Weathering of rock occurs under processes involving mechanical and chemical actions and effects the rock mass properties. This phenomenon causes a decrease in the density and strength of rock. Various types of minerals including sheet minerals such as mica and chlorite, hard minerals for example quartz, swelling clay minerals, soluble carbonate minerals influence mechanical properties of intact rock (Palmstrom \& Stille 2015). Figure 2 illustrates the main features of rock mass structures. The initial data for characterisation of rock structures in underground projects in a green field study is usually collected from engineering geological survey and drilling borehole. Engineering geological mapping provides rock strength, location of weakness zones and discontinuity properties (Palmstrom \& Stille 2015). Data collection techniques with geological and 
geotechnical mapping and core logging methods are applied to link information to describe the rock mass composition. Exploratory drilling can provide the most information for planning and design of projects. Presence of shear zones and faults have potentially detrimental effects in mining excavations. Since discontinuities properties affect ground behaviour surrounding opening, mechanical joint properties such as spacing, orientation and joint wall conditions should be considered. Also, an equivalent of size and shape of rock block in rock masses is estimated, which may be used in design stability analysis.

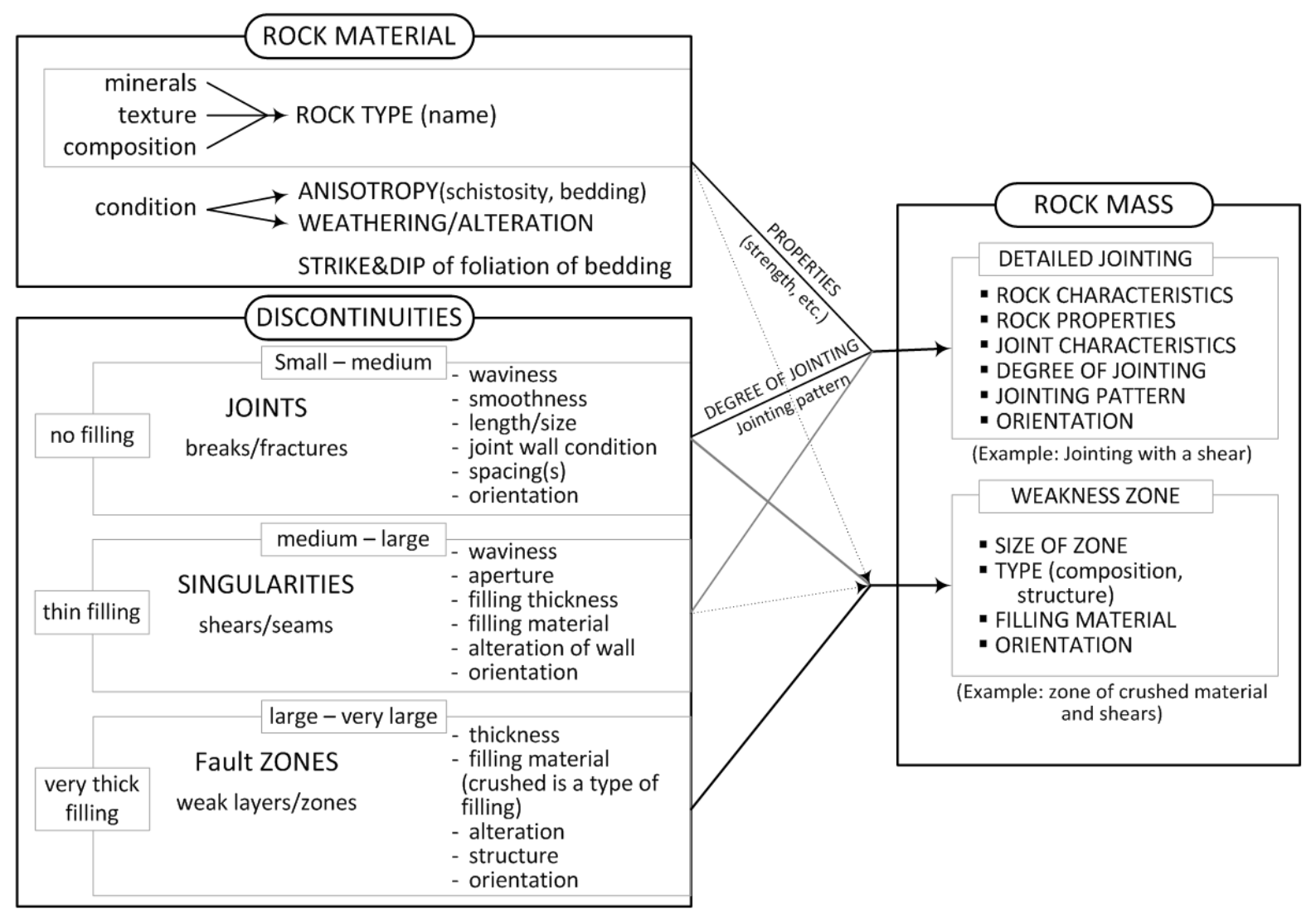

Figure 2 The main features related to rock mass structure (Palmstrom 2015)

Rock mass characterisation is based on quantitative and qualitative site investigation and laboratory tests (Potvin et al. 2015). The type of project, topographical and geological condition, in situ stress and groundwater condition are some of the relevant parameters for selecting investigation principles. Geophysical techniques are used to estimate rock mass properties and geometry of orebodies. Ground instability hazards depend on the orientation of faults, the nature of fault material, mechanical rock properties, groundwater and size of openings. The usual methods to characterise rock mass structure are listed to follow (Brown \& Rosengren 2000):

- Drilling and core logging.

- Geotechnical scanline mapping.

- Rock mechanics laboratory/field testing.

- Borehole logging.

- Analysis of data and determination of quantitative geometry of rock mass.

- Simulation of rock mass geometry by 3D statistical models.

- Rock mass classification based on the engineering parameters most relevant to the application. 
Figure 3 represents the main types of rock mass structures in ground conditions. Rock engineers and engineering geologists play a key role in the creation of a reliable model of the ground conditions and geological structures based on experience, engineering judgement and their knowledge. Identification of intact rock properties, discontinuity characteristics, geological history, regional geological structure and in situ stress should be evaluated. Based on the information obtained rock mass structure is classified into intact/massive, jointed/blocky/bedded, blocky/folded, disintegrated/crushed/soil, and special minerals types. Ground conditions and failure mechanisms in underground excavation design are evaluated based on the description of rock mass structure.

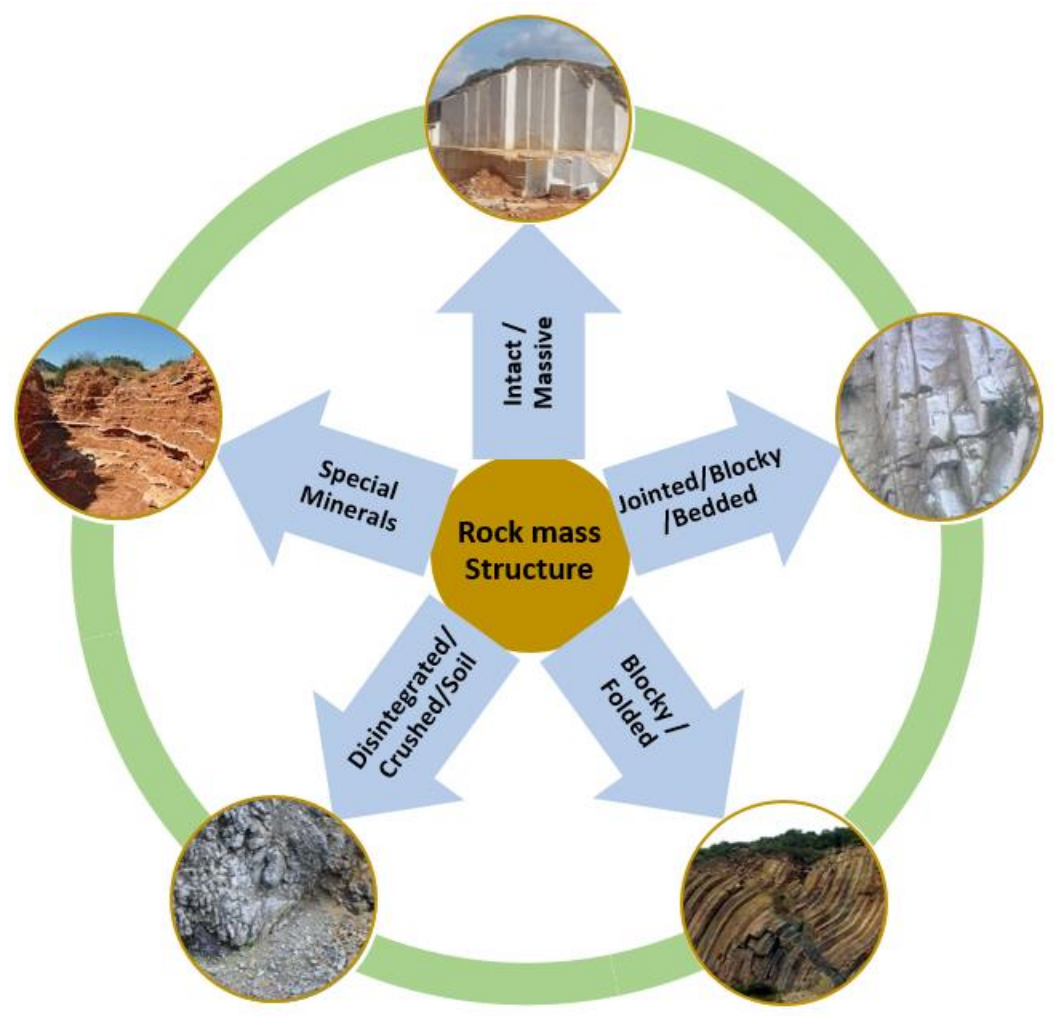

Figure 3 The main types of rock mass structure in ground conditions

\subsection{Rock mass structure at Karari mine}

The Karari deposit is located approximately $110 \mathrm{~km}$ north - east of the Kalgoorlie-Boulder city in Western Australia. The project area is in the Norseman-Wiluna greenstone belt of the Achaean Yilgarn Carton within the Gundockerta (Gray et al. 2005). Figure 4 shows geology information and location of the deposit on the map. The eastern part of the geological formation is dominated by coarse-grained monzonite and porphyritic monzonite. The central part of the deposit is formed of volcanoclastic sediments and intruded dykes of monzonite and lamprophyre. The geological formation in the western part consists of fine to coarse-grained sandstone and siltstone (GCMP 2015). The main feature of the geological structure in the surrounding Karari deposit involves the hanging wall fault with a northwest strike which separates the eastern part and the central part of the mineralised zone. Similarly, the central and footwall sedimentary sequence is separated by the footwall fault and consists of several metres of chlorite alteration. Uniaxial compressive strength varies from 50-100 MPa for the rock types encountered. Meanwhile, engineering geological mapping indicate several joint sets in the mine area with a range of dip/dip direction of $\left(30-70^{\circ}\right) /\left(50-300^{\circ}\right)$. Trace length of joints varies between $2 \mathrm{~m}$ to $10 \mathrm{~m}$. Rock types have mostly been discoloured due to weathering action. Figure 5 shows rock mass structure in the mine. Rock blocks have been formed by intersecting joints distributed such that the interlocking is determined as medium to good. The joint roughness is mostly classified as slightly rough to rough. Also, surfaces between joints are often clean. Weathering is recognised as discoloured surface rock. Furthermore, sodic alteration, which is in direct contact with sodic minerals and 
groundwater, is locally visible in the rock zones of the mine (Figure 5(c)). Based on the ground investigations and surveys, rock mass structure in the portal access of the mine is classified as jointed/blocky/bedded.

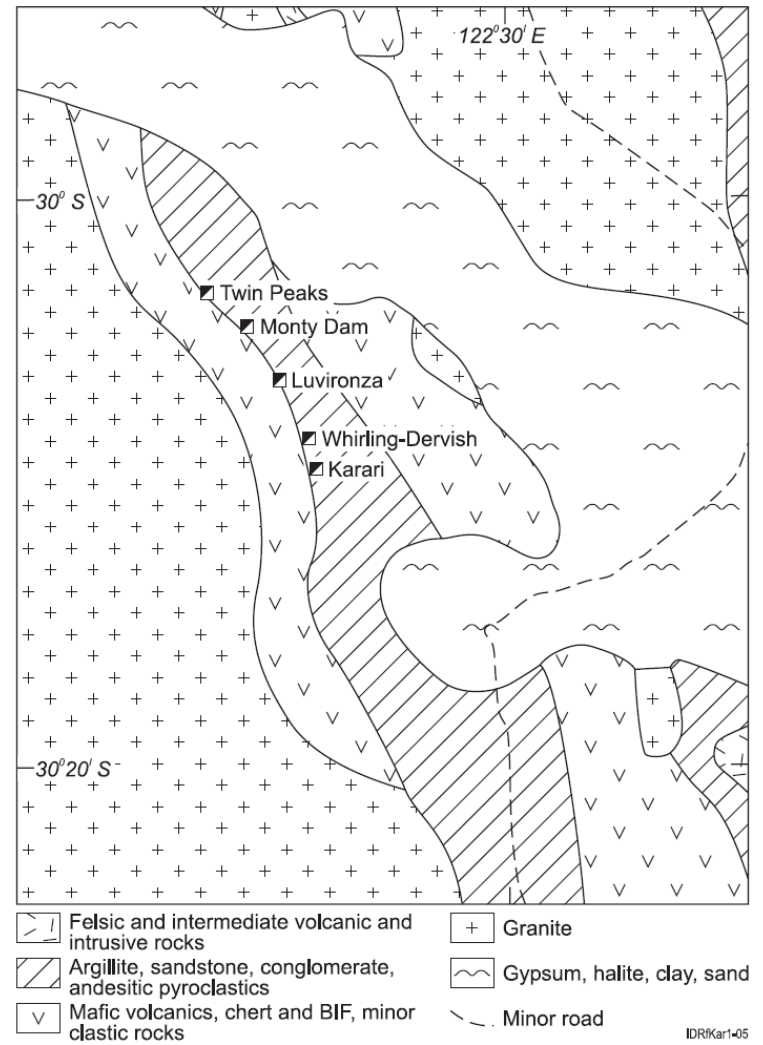

Figure 4 Geology information and location of project area on the map (Gray et al. 2005)

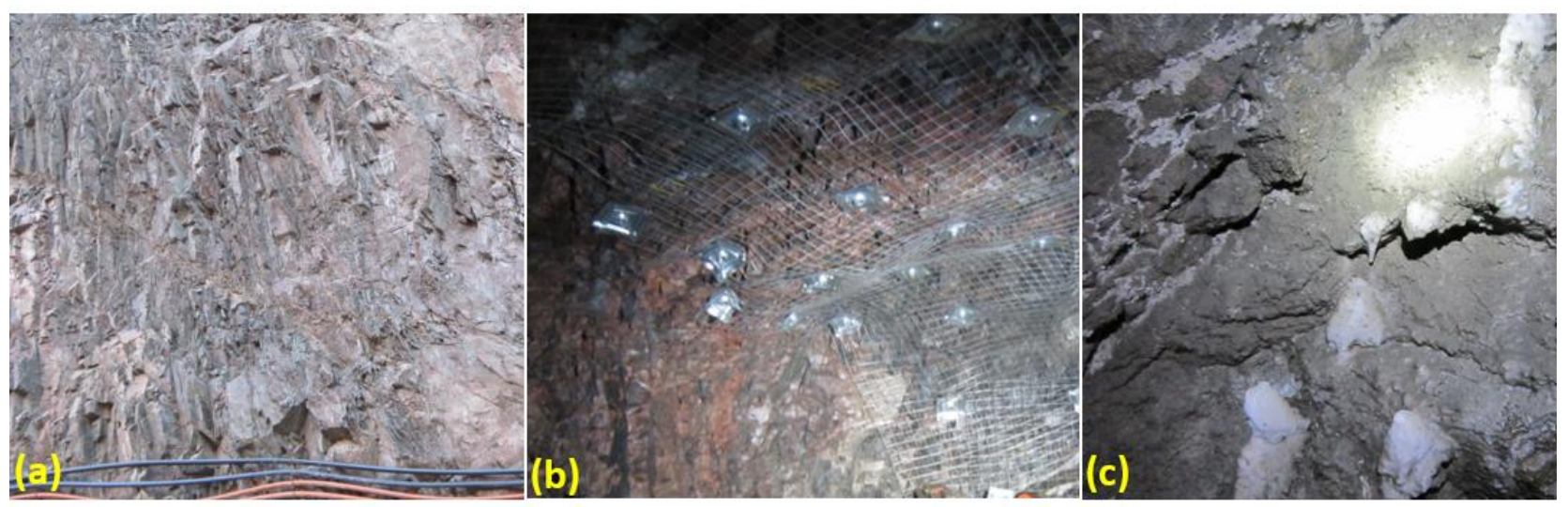

Figure 5 Rock mass structure: (a) surface area; (b) underground area; and (c) sodic alteration in the mine

\section{Expected ground behaviour modes}

Ground behaviour modes not only depend on rock mass structures, but also depend on excavation geometry and construction methods. Precise observation and careful interpretation of the available evidence in rock mass structures in the environment is the first principle in diagnosing ground behaviour (Kaiser \& Kim 2008). At great depth, when failure in ground conditions is not predicted or distinguished, rock mass may behave in unforeseen ways and sometimes the condition of good ground decreases in quality due to a variety of factors such as blasting quality. Meanwhile, misunderstood or incorrect prediction of ground behaviour may lead to using improper numerical modelling and consequently assessing implausible stability conditions for rock underground structures. There are different modes of ground behaviour such as block falls, buckling, plastic behaviour and rockburst based on failure modes in underground openings. Generally, gravity, stress and 
groundwater are the main factors related to the different types of rock mass behaviour. Block falls are usually caused by gravity. High stress levels in rock structures may lead to squeezing phenomenon. Flowing ground is an example of rock behaviour which mainly occurs in disintegrated rock masse with low cohesion and groundwater. Identification of main reasons of ground behaviour assist to distinguish types of rock failure.

Figure 6 represents different types of failure modes in underground openings. Typically, the most types of ground mode behaviours are associated with shear failure along rock blocks (Kaiser \& Kim 2008). The ratio of maximum tangential stress $\left(\sigma_{\max }\right)$ to uniaxial compressive strength $\left(\sigma_{c}\right)$ is defined as damage index (Di) or induced stress concentration factor; $\mathrm{Di}$ is a convenient behaviour indicator in underground structures (Kaiser et al. 2000). Different types of tensile and brittle failure at depth need to be managed and controlled by using an appropriate rock support and reinforcement system.

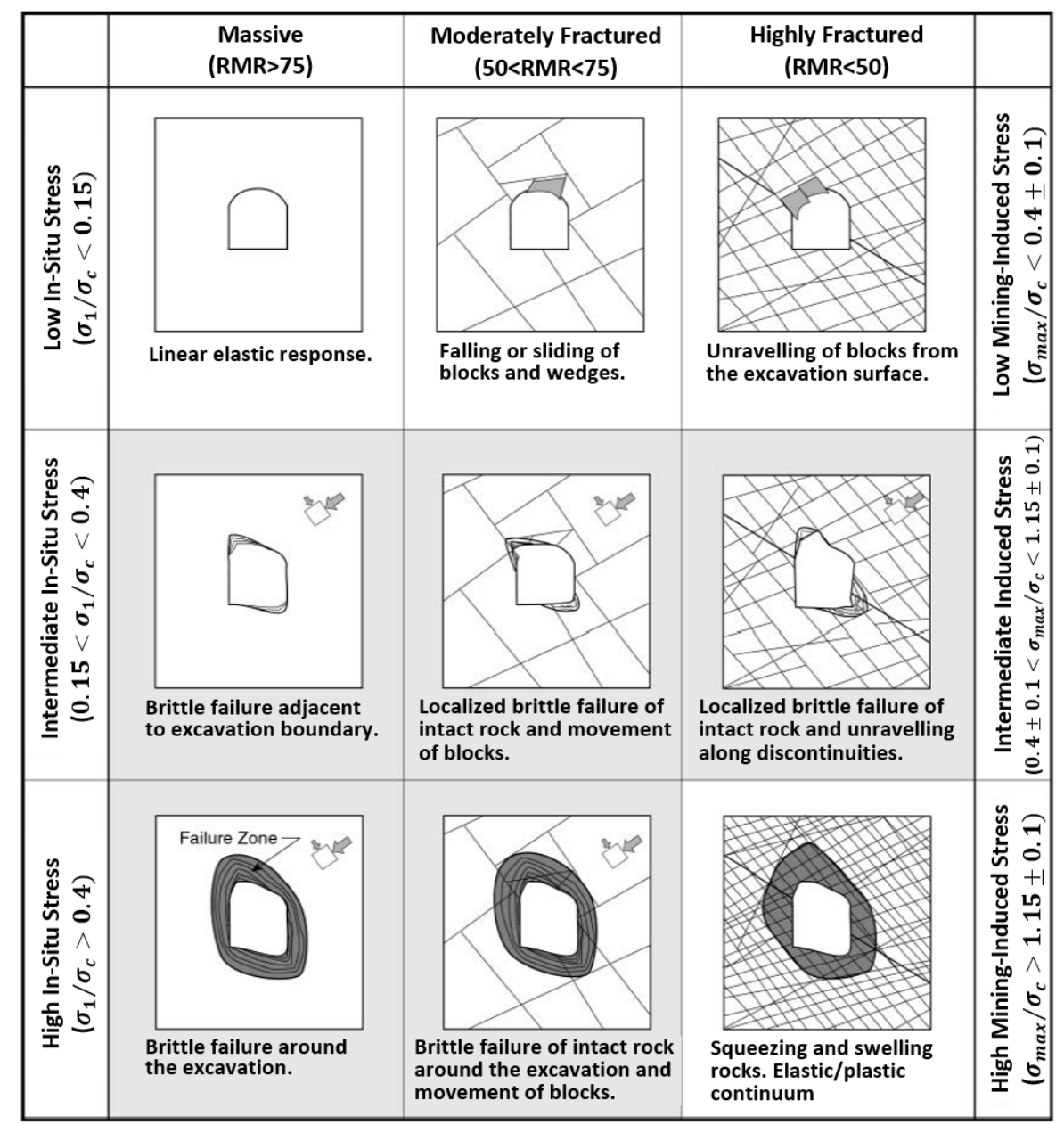

Figure 6 Different failure modes in underground excavations (Kaiser \& Kim 2008)

Rock mass behaviour and its change is not always recognised as warning signs of failure. A procedure that is capable to predict geotechnical failure can be a key tool to warn rock engineers in potential catastrophes. Analysis of case studies indicates that progressive failure in rock masses have warning signs as indicators and precursors (Szwedzicki 2003). Geological features like joints, faults and folds make the rock mass more prone to failure. Considering indicators and precursors assists to predict and avoid local damage and collapse in mining operations.

Considering rock structure type, excavation condition and stress concentrations, rock behaviour around excavations could be classified into stable/elastic, intact rock failure, structural/intact, structural failure, and water effect. Figure 7 illustrates the main types of ground behaviour and failure modes in rock underground practices. In a real ground condition, rock engineers are commonly encountered with more than one type of rock behaviour and failure mechanism. Therefore, evaluation of several/combination ground behaviour in a 
one project can be essential to fair control of rock failure and hazard. In the stable/elastic state, rock mass structure surrounding an underground excavation is strong enough to support itself in confronting unstable conditions such as block fall. Intact rock failure is mostly associated with a rock mass consisting of a few joints so that the rock mass properties are almost similar to intact rock. In this case, a variety of failure modes may be encountered such as plastic, squeezing and rockburst based on in situ stress condition, geometry of excavation, rock type and groundwater condition. In the structural/intact state, the behaviour of rock mass may follow intact rock properties or rock mass structures depending on the degree of jointing. Block fall, sliding and toppling are the usual failure modes for this state. Structural failure is related to behaviour of rock mass in a large scale and in a variety of conditions such as high degree of jointing, high stress condition, low rock mass strength and etc. The presence of groundwater influences special minerals such as clay and montmorillonite and causes swelling in ground condition. In addition, the type of failure in brecciated and disintegrated may involve low cohesion of rock material and it can result to ravelling or flowing ground. Weathering by mechanical and chemical process affects the nature of rock, and based on temperature, climate, water, degree of rock fracture and minerals conditions reduce the strength of rock materials. Some minerals like as olivine, calcite and pyroxene have low stability compared to quartz and aluminium hydroxides under weathering. (Hencher 2012; Lafrance et al. 2016). Hence, rocks with high rate of weathering minerals are more prone to failure. Production or concentration of gas in some geological structures especially in coal mines may lead to outburst rock (Aziza et al. 2011). Drainage of gas reduces in situ quantity and controls outburst hazards. Weak rocks have low strength because of jointing or rock material like as shales, mudstone and tuffs. Failure of these types can occur without water and even without low friction materials. Moderate in situ stress levels cause failure in the weak rock surrounding underground openings (Hoek 2006). Shear zones and faults around weak rocks can cause sudden and uncontrolled collapse.

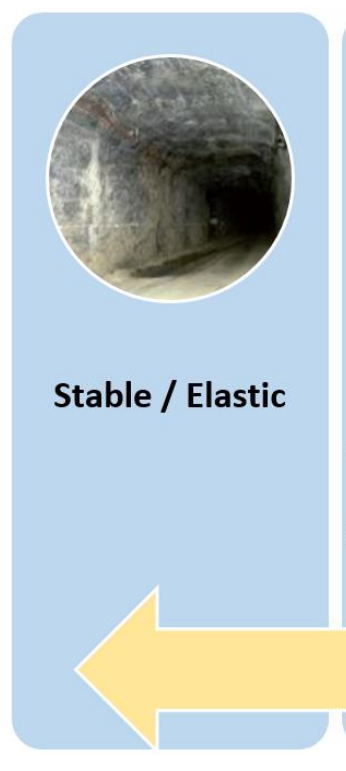

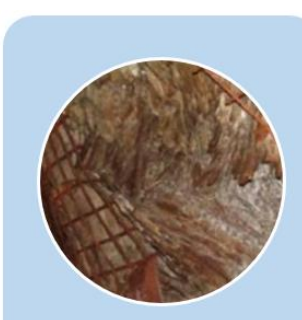

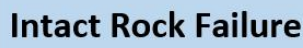

(Plastic, squeezing, brittle, Slabbing spalling, Rockburst)

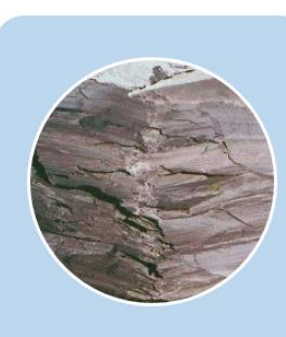

Structural/Intact

(Buckling, Tensile splitting, Shearing)

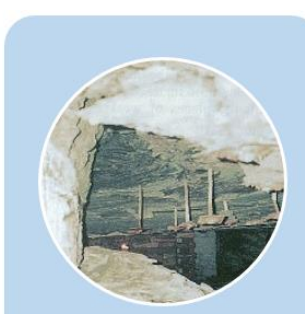

Structural Failure (Block fall, Sliding, Toppling)

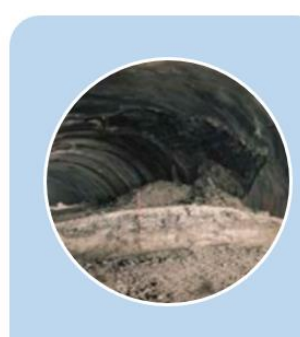

\section{Water Effect} (Swelling, Flowing, Ravelling)

Main Ground Behaviour Type in Underground Excavation

Figure 7 Ground behaviour types and failure modes in rock underground excavations

\subsection{Ground behaviour at Karari mine}

The ground condition in the Karari mine indicates that the quality of rock mass varies from very poor (mostly in major faults and shear zones) to very good and the $Q$ value is between $0.3-75$ (GCMP 2015). The rock mass structure in the portal access classified as joined/blocky/bedded. Figure 8 shows a schematic of rock mass structure and interlocking rock blocks in the mine. There is a potential rock fall failure due to loosening of rock blocks in the roof and wall. Groundwater, alteration and degree of jointing can influence the volume of rock fall. Since that the rock mass is blocky, wedge sliding or gravity failure can occur, and mechanical and geometrical properties of joints mainly control stability of falling or sliding blocks. Rock mass around shear zones is highly fractured and brecciated. It is expected occurring ravelling ground behaviour in this area. In 
spite of in situ stress measurements not being carried out in the mine (GCMP 2015), there is a possible failure due to stress induced in the opening. Therefore, diagnosis of ground behaviour in the portal access area is established as 'intact rock failure', 'structural failure' and 'water effect'.
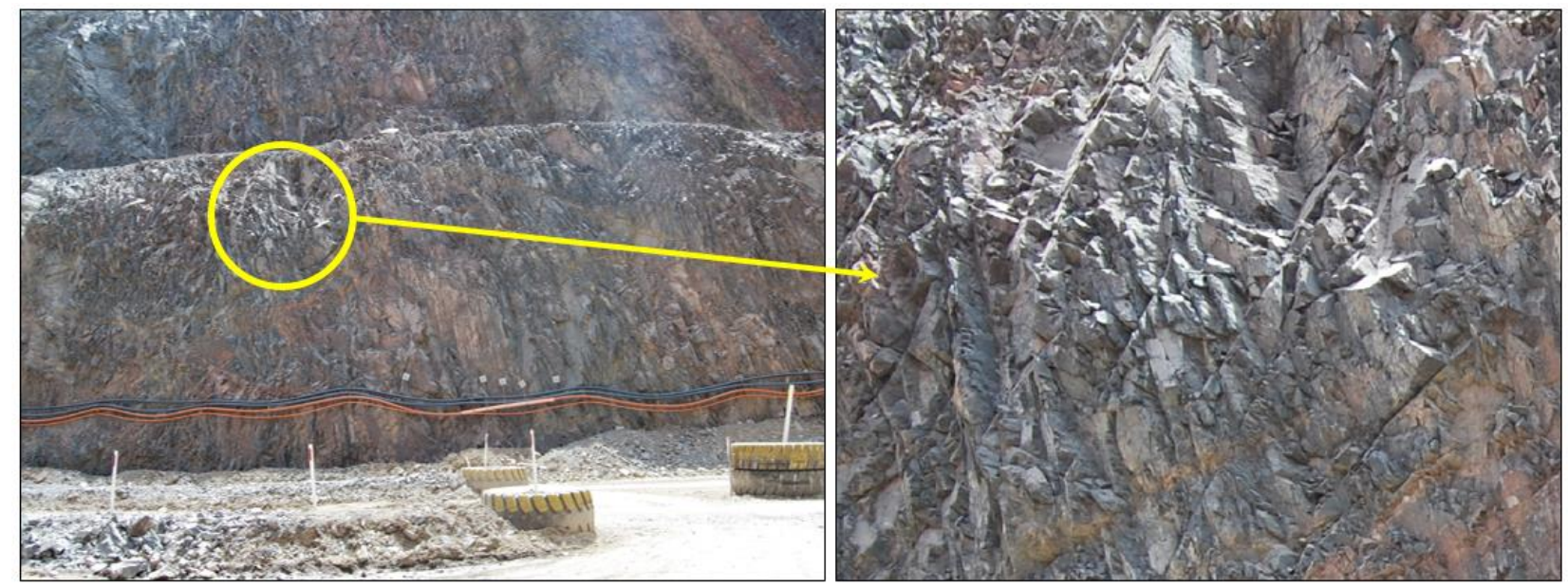

Figure 8 A schematic of quality rock mass structure and rock blocks in the mine

\section{Observed common failures}

Rock mass behaviours and failure modes usually determine the design process in underground excavations. Stress condition and rock structure affect the mode of failures. Failure modes can differ in hard rock compared to soft rock, and also at shallow depth compared with great depth. Rock failure is due to creation, growth, accumulation and interaction of microcracks. Microcracks inside rocks are initiated by exceeding stress levels at depth and behaviour of rock mass during the failure process can change from a continuum condition (intact to moderately fractured) to a discontinuous state, such as slabbing or spalling ground mode (Hajiabdolmajid \& Kaiser 2003). The usual failures in underground mines include block fall, shear failure, swelling, rockburst, squeezing and chimney type failure (in highly fractured) rock mass condition. Some of them are briefly discussed below.

\subsection{Block fall}

Block fall is a common failure in some mines. Geological structure and composition, in situ stress, groundwater condition, layers with different strength, improper ground support, and extraction ratio affect the failure in underground mines. It's impossible to avoid block failure in underground mines. However, ground control and management can diminish it. Selection of suitable mining methods (consisting of utilised equipment, blasting method and backfill), infrastructure layout of mines, and mining sequences are some of the useful strategies to control failure (Potvin \& Nedin 2003). Application of mesh with rockbolts can be beneficial in jointed and weathered rock mass to avoid falling rock from roof top in the mines (Figure 9). It is clear that technical and economic conditions usually determine the types of ground support and reinforcement systems in the projects. 


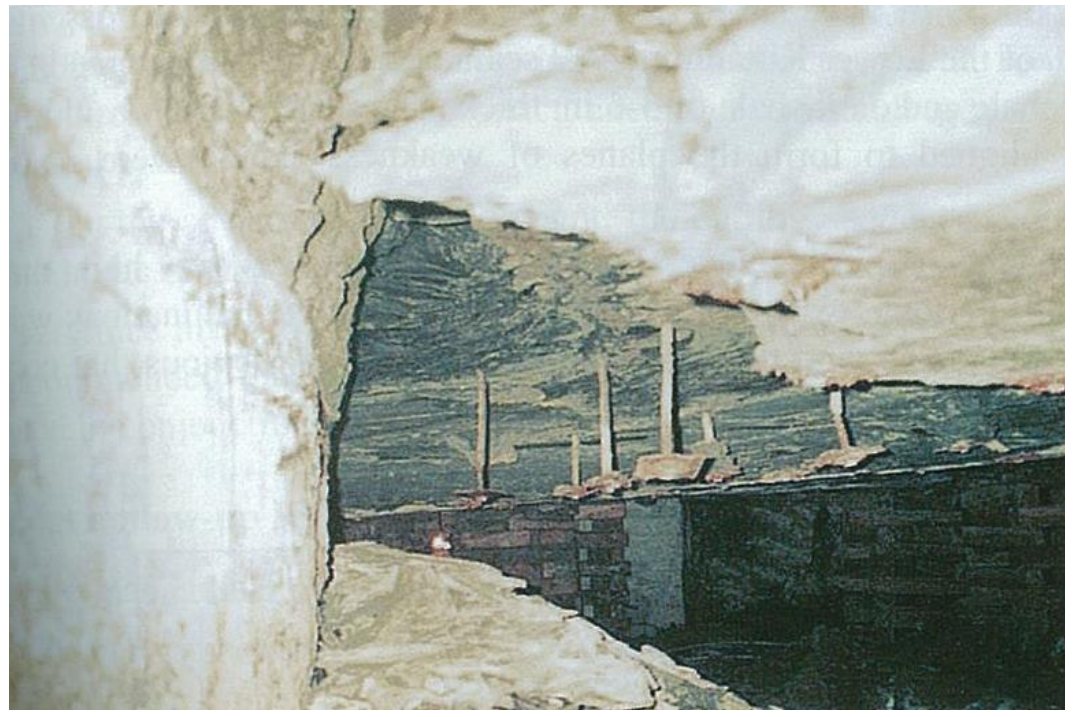

Figure 9 Block failure in underground mine (Peng 2007)

\subsection{Rockburst and rock ejection}

A trend to extract deeper in underground mines is related to higher induced stress in rock masses and may cause rock to eject violently or rockburst (due to seismic sources) because of the sudden release of stored energy. Various factors affect the rockburst damage like as stress level, rock strength, geological structures, depth, opening geometry, lateral extent of rock around opening, seismic-induced stress, ground support efficiency and stiffness of mines or openings (Kaiser et al. 1996). The most important relevant factors in rockburst behaviour has been illustrated in Figure 10. Rock mass strength and stress condition are the useful indicators to evaluate rockburst behaviour. Table 1 presents a classification of rockburst failure based on ratio of the intact rock strength and tangential stress parameters $\left(\sigma_{c} / \sigma_{\theta}\right)$. Rockburst mechanism is based on overstress rock zones in an unstable equilibrium condition so that causes the failing structures as a rapid ejection of broken rock and stress drop (Jager \& Ryder 1999).
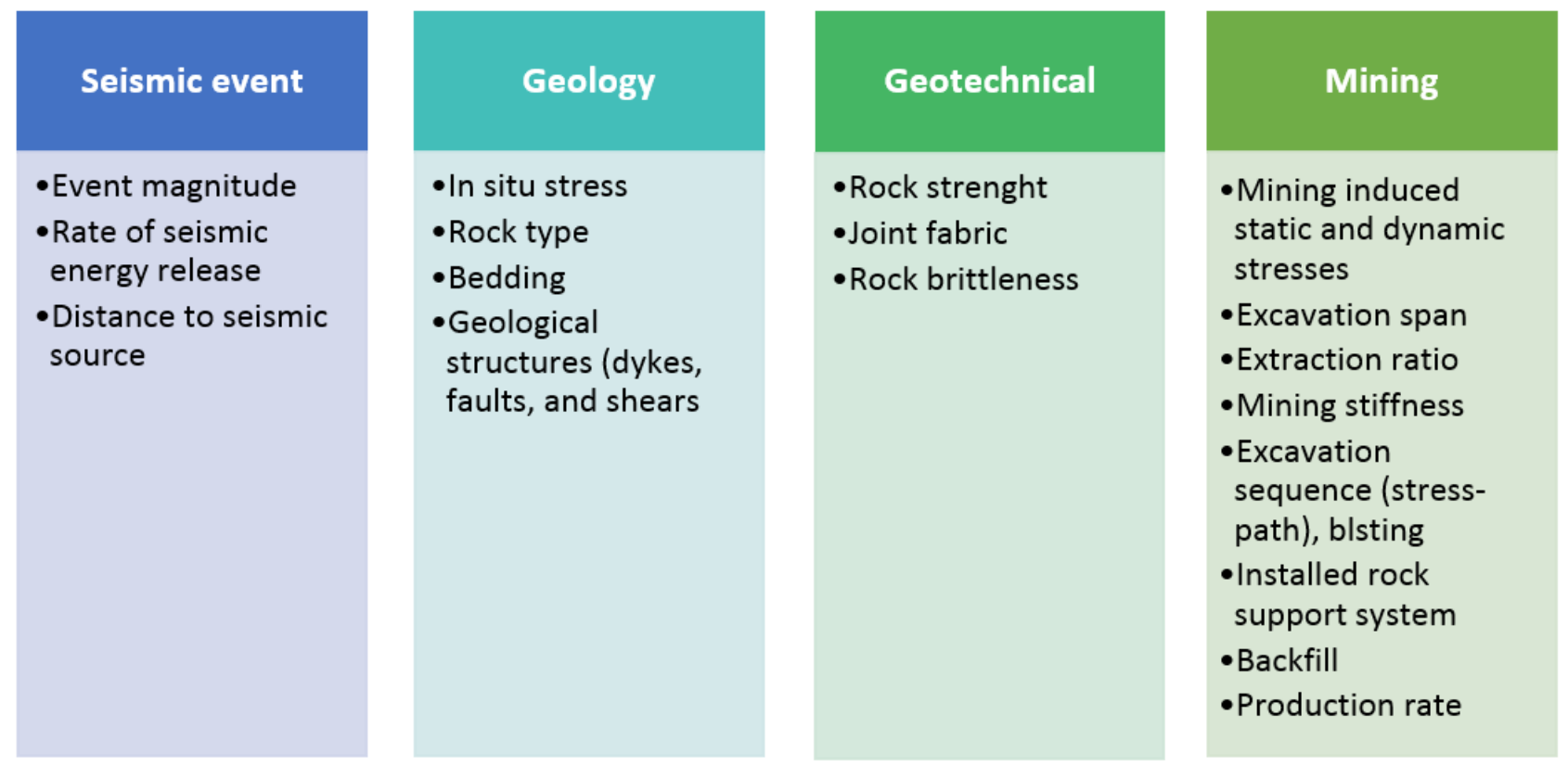

Figure 10 Main factors in rockburst behaviour (Kaiser \& Cai 2012) 
Table 1 Classification of rockburst behaviour based on empirical methods (Ozturk 2013)

\begin{tabular}{|c|c|c|c|c|}
\hline \multicolumn{4}{|c|}{ Value of the ratio $\sigma_{c} / \sigma_{\theta}$} & \multirow[t]{2}{*}{ Description } \\
\hline $\begin{array}{l}\text { Russenes } \\
\text { (1974) }\end{array}$ & $\begin{array}{l}\text { Hoek and } \\
\text { Brown (1980) }\end{array}$ & $\begin{array}{l}\text { Grimstad } \\
\text { and Barton } \\
(1993)\end{array}$ & $\begin{array}{l}\text { Palmstrom } \\
\text { (1996) }\end{array}$ & \\
\hline & & $>100$ & & Near surface, low stress, open joints \\
\hline$>4$ & $>7$ & $100-3$ & $>2.5$ & $\begin{array}{l}\text { No rock spalling/stable/medium, favourable } \\
\text { stress condition/no rock stress-induced } \\
\text { instability }\end{array}$ \\
\hline $4-3$ & $7-3$ & $3-2$ & $2.5-1$ & $\begin{array}{l}\text { Low rock spalling/minor spalling/high stress, } \\
\text { very tight structure/high stress, slightly } \\
\text { loosening }\end{array}$ \\
\hline $3-1.5$ & $3-1.7$ & $2-1.5$ & -0.5 & $\begin{array}{l}\text { Moderate rock spalling/severe spalling/ } \\
\text { moderate slabbing after } 1 \mathrm{hr} / \text { light rockburst } \\
\text { or spalling }\end{array}$ \\
\hline$<1.5$ & $1.7-1.4$ & $1.5-1$ & $<0.5$ & $\begin{array}{l}\text { High rock spalling/heavy support } \\
\text { required/slabbing and rockburst/heavy } \\
\text { rockburst }\end{array}$ \\
\hline & $<1.4$ & $<1$ & & Heavy rockburst/severe rockburst \\
\hline
\end{tabular}

Designing rock support for burst conditions is different from traditional approaches that is mainly controlling for gravity of rock falls and shallow zones of loose rock. In burst ground conditions, rock support and reinforcement system should endure dynamic loads and large deformations because of rock dilation (bulking) during intensive failure (Kaiser \& Cai 2012). Understanding of loading mechanism, rock mass failure mechanism, and mechanism of action and interaction of support elements in rockbursting condition is necessary to achievement a desire results of rock support design (Stacey 2012). Selection appropriate support system and excavation methods can reduce rockburst hazard.

\subsection{Squeezing ground}

Squeezing ground behaviour is identified by large scale deformation in underground excavations. It may occur not only in weak rock mass conditions but are also observed in hard rock with high stress and be of major concern during the construction and conservation of underground mining openings (Mercier-Langevin \& Hadjigeorgiou 2011). Deformation of underground openings sometimes reach tens of centimetres in squeezing ground conditions. In this type of ground condition, stopping deformation is not generally accepted and the focus should be to control and manage ground movement (Woolley \& Andrews 2015). Evaluation of rock mass stability is the main concern of squeezing problems due to the deformation of rock mass which may happen over a few days. The classification of squeezing potential has been shown in Table 2 . Several empirical methods are used to determine the type of squeezing ground behaviour based on rock mass strength $\left(\sigma_{c m}\right)$, critical depth $(\mathrm{H})$ and tangential stress. Severity of displacement and failure increase from no squeezing to heavy squeezing state. Weakness geological features such as faults, clay minerals and foliation considerably affect squeezing failure. 
Table 2 Classification of squeezing potential in underground excavations (Ozturk 2013)

\begin{tabular}{|c|c|c|c|c|c|}
\hline $\begin{array}{l}\sigma_{\theta} / \sigma_{\text {cmass }} \\
\text { ISRM }\end{array}$ & $\begin{array}{l}\sigma_{c m} /(\gamma H) \\
\text { Jethwa et al. }\end{array}$ & $\begin{array}{l}\sigma_{c m} /(\gamma H) \\
\text { Barla }\end{array}$ & $\begin{array}{l}\mathrm{RMi} / \sigma_{\theta} \\
\text { Palmstrom }\end{array}$ & Squeezing class & Definition \\
\hline$<1$ & $>2$ & $>1$ & $>1$ & No squeezing & Stable \\
\hline $1-2$ & $0.8-2$ & $0.4-1$ & $0.7-1$ & $\begin{array}{l}\text { Mildly/light } \\
\text { squeezing }\end{array}$ & $\begin{array}{l}\text { Stable, displacements with } \\
\text { converge }\end{array}$ \\
\hline $2-4$ & $0.4-0.8$ & $0.2-0.4$ & $0.5-0.7$ & $\begin{array}{l}\text { Moderately } \\
\text { squeezing }\end{array}$ & $\begin{array}{l}\text { Larger displacement with } \\
\text { converge }\end{array}$ \\
\hline \multirow[t]{2}{*}{$>4$} & $<0.4$ & $<0.2$ & $0.35-0.5$ & $\begin{array}{l}\text { Highly/heavy } \\
\text { squeezing }\end{array}$ & $\begin{array}{l}\text { Displacement will be large } \\
\text { and will not tend to } \\
\text { converge }\end{array}$ \\
\hline & & & $<0.35$ & $\begin{array}{l}\text { Very heavy } \\
\text { squeezing }\end{array}$ & $\begin{array}{l}\text { The rock flows, } \\
\text { displacement will be very } \\
\text { large, install heavy support }\end{array}$ \\
\hline
\end{tabular}

\section{$5 \quad$ Ground management outline}

Ground control or management is a process to predict and manage rock behaviour and failure conditions in underground openings. The knowledge of ground condition plays a considerable role in pillar design, support design, stability analysis of slopes, instrumentation selection, roof controls and so on. Knowledge and understanding of rock mass properties are the fundamental steps for managing ground conditions in design processes. Modern rock engineering practice is not possible without evaluation of ground behaviour in underground excavations. Warning signs such as faults, joints, moisture and folds in underground mines assist to forecast potential failure. Selection of proper design methods is performed based on the failure mechanism and the availability of data required by design tools. Geotechnical investigations and ground control management should be carried out during the whole life of projects from feasibility study stage to the final mine closure. Ground condition and potential hazards are used to determine the type of rock support and reinforcement systems in underground excavations. A typical design procedure for ground support is listed below (Thompson et al. 2011):

- Hazard recognition and failure mechanism.

- Support demand estimation.

- Estimation of ground demand.

- Energy demand forecast.

- Selection of proper rock support and reinforcement pattern and installation.

- Evaluation of rock structure reaction to ground support and reinforcement.

- Modification of scheme of support system if required.

Rock support and reinforcement elements should provide resistance to unstable rocks. Since it may be used a variety types of external and internal devices together as a ground support, a satisfactory situation is compatibility of deformation between them in rock masses (Li 2015). Ensuring compatibility of a support elements with reaction of the host rock mass structure enhances the safety. Figure 11 shows a schematic of incompatibility and compatibility of deformation in external and internal support tools in underground excavations. An incompatibility condition of a support system may lead to failure of rockbolts and therefore expose external device support systems to an overstress condition. Rock support demands can be supplied by deformable, reliable and strong devices in high stress conditions. The control of design parameters in the 
construction phase is carried out by field measurements to verify the agreement between the disturbed rock mass structure and the design parameters and then allow the parameters in the design process to be modified.
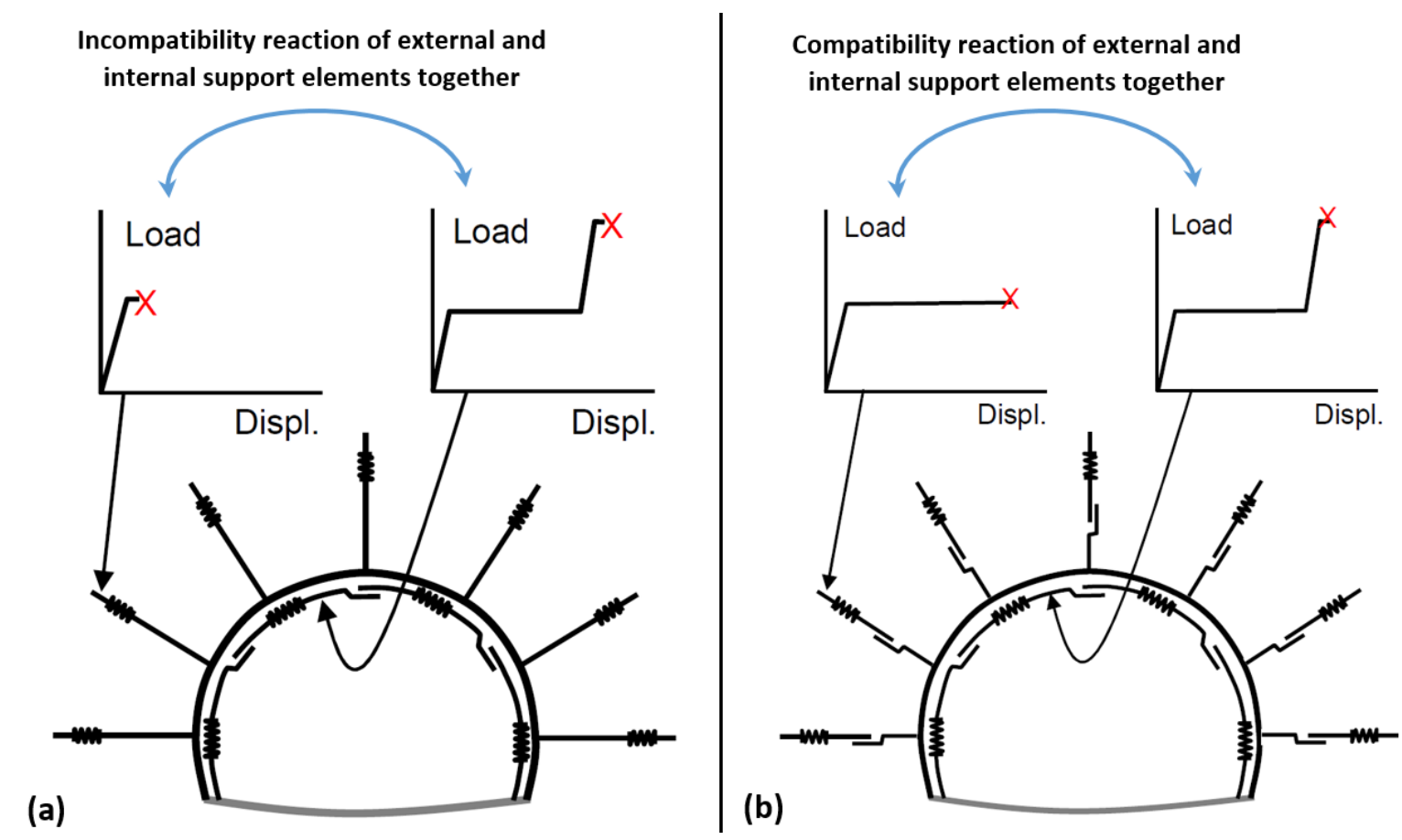

Figure 11 A schematic of (a) incompatibility; and (b) compatibility of deformation between external and internal support elements (Li 2015)

\subsection{Ground management outline in Karari mine}

Rock mass structure was characterised as jointed/block/bedded in the Karari mine. In addition, the main and important type of failure risks was assessed as block fall. Reinforcing rock blocks can be carried out by using rockbolt to avoid loosening strength of rock mass which is associated with instability condition. It is possible occurrence of the block fall or skin fall between two rockbolts due to highly joined rock, so using mesh with rockbolt restricts skin falls in the roofs and walls. Meanwhile, application of shotcrete with rockbolt and mesh provide retaining broken rock in faults and shear zones areas. Simplicity, quick installation, flexibility in different ground condition can justify using rockbolt, mesh and shotcrete (in weak zones) as a primary considering ground support system in the mine. However, in detailed design process comparison of different types of support and reinforcement devices are required based on technical and economic conditions. The portal access is nominally $5.5 \mathrm{~m}$ wide and $5.7 \mathrm{~m}$ high, and excavation is implemented by drilling and blasting method. Blasting excavation method often causes extending of existing discontinuities and fractures in the rock mass. It is usually to change the properties of rock mass and performance of rock structure and probably ground behaviour surrounding the portal. Control or smooth blasting method can be employed to decrease the thickness of excavation damage zone. In very weakness zone areas (fault and shear zones), using sequential excavation method can lessen overbreak of the rock, damage area and failure risks. Since the dimension of portal access is not large, using sequential method may increase the time of excavation process. Hence, the primary planning to ground management in the Karari mine is outlined as using rockbolt with mesh, and also shotcrete, and smooth blasting method/or sequential excavation method in the weak rock zones. Figure 12 shows an example of rockbolts with mesh in the roof installed as ground support in the mine. 

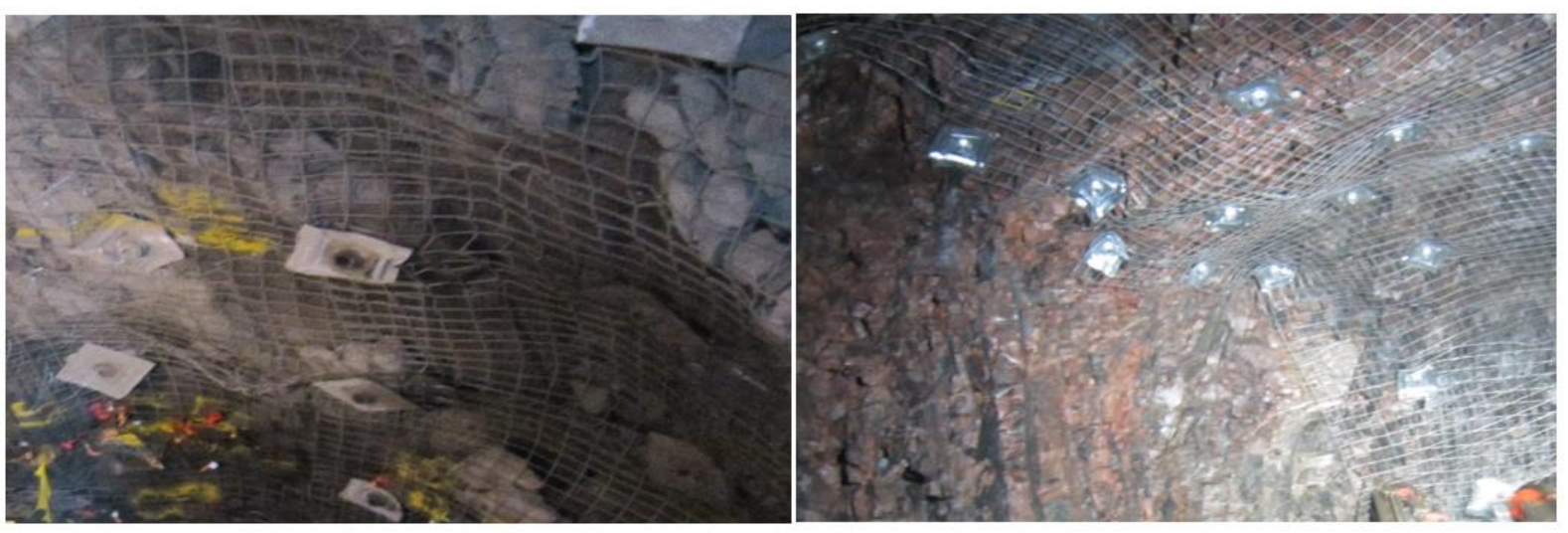

Figure 12 Installed ground support in the mine

\section{Conclusion}

Underground excavation design necessitates knowledge of rock mass structure, ground behaviour and failure modes. The proposed classification for rock mass structure is divided into intact/massive, jointed/blocky/ bedded, blocky/folded, disintegrated/crushed/soil and special mineral classes. Understanding rock mass composition provides information to assess the probable ground behaviour and failure mode. In addition, the main behaviour types proposed are stable/elastic, intact rock failure, structural/intact, structural failure, and water effect groups. Planning for ongoing ground management is required in the design procedure because it is impossible to control ground conditions. Ground management is established based on three main factors: experience, management systems and knowledge. The design procedure for underground excavation, developed from existing procedures, has six steps with headings: rock mass structure, diagnosis of ground behaviour, failure mechanism, design analysis, construction, and field measurement. This procedure is applied, based on ground management, to provide safety surrounding rock structure. Consideration of the rock mass structure in the Karari mine determined a jointed/blocky/bedded class for the portal access area. The main types of expected failure assessed as rock fall and stress induced failure. Evaluation of rockbolt and mesh, and shotcrete (in weak rock zone) as ground support systems were defined as a basic outline for ground management in the mine. While the implementation of a smooth blasting or sequential excavation method can reduce damage area and failure risk in the mine.

\section{References}

Aziza, N, Black, BD \& Rena, T 2011, 'Mine gas drainage and outburst control in Australian underground coal mines', Procedia Engineering, vol. 26, pp. 84-92.

Bieniawski, ZT 1992, Design Methodology in Rock Engineering: Theory, Education and Practice, Balkema, Rotterdam.

Brown, ET \& Rosengren, KJ 2000, Characterising the mining environment for underground mass mining, The Australasian Institute of Mining and Metallurgy, Carlton South, viewed 23 December 2016, http://www.onemine.org/document/abstract.cfm? docid $=189385$

Cai, M 2013, 'Principles of rock support in burst-prone ground', Tunnelling and Underground Space Technology, vol. 36, pp. 46-56. GCMP, SKU 2015, Karari Underground Ground Control Management Plan, Saracen Gold Mines Pty Limited, Perth, Western Australia.

Gray, DJ, Robertson, IDM, Cornelious, M, Sergeev, NB \& Porto, CG 2005, 'Karari and Whirling Dervish Gold Deposits, Western Australia', in CRM Butt, IDM Robertson, KM Scott \& M Cornelius (eds), Regolith Expression of Australian Ore Systems, CRC Leme, Perth, Western Australia, pp. 274-275.

Grimstad, E \& Barton, N 1993, 'Updating of the Q-System for NMT', in R Kompen, OA Opsahl \& KR Berg (eds), Proceedings of the International Symposium on Sprayed Concrete - Modern Use of Wet Mix Sprayed Concrete for Underground Support, Norwegian Concrete Association, Oslo, pp. 46-66.

Hajiabdolmajid, V \& Kaiser, P 2003, 'Brittleness of rock and stability assessment in hard rock tunnelling', Tunnelling and Underground Space Technology, vol. 18, pp. 35-48.

Hencher, S 2012, Practical Engineering Geology, Spon Press, New York, USA.

Hoek, E 2006, Practical Rock Engineering, Evert Hoek Consulting Engineer Inc, North Vancouver, British Columbia.

Hoek, E \& Brown, ET 1980, Underground Excavations in Rock, Institution of Mining and Metallurgy, London, pp. 527.

Jager, AJ \& Ryder, JA 1999, A Handbook on Rock Engineering Practice for Tabular Hard Rock Mines, The Safety in Mines Research Advisory Committee, Braamfontein, Johannesburg. 
Kaiser, PK, Cai, M 2012, 'Design of rock support system under rock burst condition', Journal of Rock Mechanics and Geotechnical Engineering, vol. 4, no. 3, pp. 215-227.

Kaiser, PK, Diederichs, MS, Martin, CD, Sharp, J \& Steiner, W 2000, 'Underground works in hard rock tunnelling and mining', Proceedings of the GeoEng 2000 Conference, Technomic Publishers Co Inc, Lancaster, pp. 841-926.

Kaiser, PK \& Kim, BH 2008, 'Rock mechanics challenges in underground construction and mining', in Y Potvin, J Carter, A Dyskin \& R Jeffery (eds), Proceedings of the First South Hemisphere International Rock Mechanics Symposium, Australian Centre for Geomechanics, Perth, pp. 23-38.

Kaiser, PK, McCreath, DR \& Tannant, DD 1996, Canadian Rockburst Support Handbook, Geomechanics Research Centre/MIRARCO, Sudbury, Ontario.

Lafrance, N, Auvray, C, Souley, M \& Labiouse, V 2016, 'Impact of weathering on macro-mechanical properties of chalk: Local pillar-scale study of two underground quarries in the Paris Basin', Engineering Geology, vol. 213, pp. 107-119.

Lang, AM, 1995, 'Ground control management for underground mining', in TS Golosinski (ed.), Proceedings of the 6th Underground Operators' Conference, 13-14 November, Kalgoorlie, The Australian Institute of Mining and Metallurgy, Carlton South, pp. 45-53.

Li, CC 2015, 'Development trend of underground rock support', in F Hassani, J Hadjigeorgiou \& JF Archibald (eds), Proceedings of the 13th International Congress of Rock Mechanics, 10-13 May 2015, Montreal, The Canadian Institute of Mining, Metallurgy \& Petroleum and International Society for Rock Mechanics, ISBN 978-1-926872-25-4, pp. 1-10.

Mercier-Langevin, F, Hadjigeorgiou, J 2011, 'Towards a better understanding of squeezing potential in hard rock mines', Mining Technology Journal, vol. 120, no. 1, pp. 36-44.

Ozturk, CA 2013, 'Support design of underground openings in an asphaltite mine', Tunnelling and Underground Space Technology, vol. 38, pp. 288-305.

Palmstrom, A 2015, Joints and Jointing, viewed 23 December 2016, www.rockmass.net/articles/geological_features /joints_and_jointing.html

Palmstrom, A, 1996, 'Characterizing rock masses by the RMi for use in practical rock engineering, Part 2: some practical applications of the Rock Mass index (RMi)', Tunnelling and Underground Space Technology, vol. 11, no. 3, pp. 287-303.

Palmstrom, A \& Stille, H, 2015, Rock Engineering, 2nd edn, Institution of Civil Engineers, Westminster, London.

Peng, SS, 2007, Ground Control Failures - A pictorial view of case studies, PhD thesis, Department of Mining Engineering College of Engineering and Mineral Resources, West Virginia University, Morgantown.

Potvin, Y, Dight, PM \& Wesseloo, J 2015, 'Some pitfalls and misuse of rock mass classification systems for mine design', in Y Potvin (ed.), Proceedings of the International Seminar on Design Methods in Underground Mines, 17-19 November 2015, Perth, Australian Centre for Geomechanics, Perth, pp. 1-12.

Potvin, Y \& Nedin, P 2003, Management of Rock fall Risks in Underground Metalliferous Mines, Australian Centre for Geomechanics, Perth, Western Australia.

Russenes, BF 1974, Analysis of Rock Spalling for Tunnels in Steep Valley Sides, MSc Thesis, Norwegian Institute of Technology, Trondheim, pp. 247.

Stacey, TR 2012, 'Support of excavations subjected to dynamic (rockburst) loading', in Qian \& Zhou (eds), Harmonising Rock Engineering and the Environment, Taylor \& Francis Group, London, ISBN 978-0-415-80444-8.

Stille, H \& Palmstrom, A, 2003, 'Classification as a tool in rock engineering', Tunnelling and Underground Space Technology, vol. 18, pp. 331-345.

Szwedzicki, T, 2003, 'Rock mass behaviour prior to failure', International Journal of Rock Mechanics \& Mining Sciences, vol. 40, pp. 573-584.

Thompson, AG, Villaescusa, E \& Windsor, CR 2011, 'Ground support terminology and classification: an update', Geotechnical and Geological Engineering, vol. 30, DOI 10.1007/s10706-012-9495-4.

Woolley, CE \& Andrews, P 2015, 'Short term - solutions to squeezing ground at Agnew Gold Mine', in Y Potvin (ed.), Proceedings of the International Seminar on Design Methods in Underground Mines, 17-19 November 2015, Perth, Australian Centre for Geomechanics, Perth, pp. 199-214. 